\title{
STRATEGI PEMERINTAH DAERAH DALAM PENGEMBANGAN PASAR AGRIBISNIS DI DESA SUMILLAN KECAMATAN ALLA KABUPATEN ENREKANG
}

\author{
Muhammad Syukur ${ }^{1}$, Muchlas M. Tahir ${ }^{1}$, Zulfan Nahruddin ${ }^{1}$ \\ ${ }^{1}$ Program Studi Ilmu Pemerintahan Fakultas Ilmu Sosial dan Ilmu Politik \\ Universitas Muhammadiyah Makassar \\ Jl. Sultan Alauddin No. 259 Makassar 90221 \\ Telp. 0411-866972 ext.107.Fax.0411-8655888 \\ msyukur0708@yahoo.co.id muchlasmtahir7@gmail.com zulfannahruddin@yahoo.co.id
}

\begin{abstract}
The purpose of this study is to determine the Local Government Strategy for the Development of Agribusiness Market in the Simillan Village District of Allla, Regency of Enrekang. The method used is qualitative. Data were collected using instruments such as: observation, documentation and developed with interviews with informants. Technical analysis of the data used in this study is a model of interactive analysis, namely: data collection, data reduction, data serving and withdrawal conclusions. The validity of the data in this study examined using triangulation techniques. These results indicate that counseling and assistance to agricultural and plantation actors government acting through the provision of guidance and direction that intensive and effective to the community as an effort to develop business systems in marketing promotion of agricultural products, the government plays as an agent that accelerates the development of regional potential strategies local governments in the development of the excellent potential in this case of vegetables and fruits by using SWOT analysis so far has been the maximum in the running srtategi maximum for use on the public especially in agriculture and plantations.
\end{abstract}

Keywords: local government, strategy, agricultural market

\begin{abstract}
ABSTRAK
Tujuan penelitian ini yaitu untuk mengetahui Strategi Pemerintah Daerah dalam Pengembangan Pasar Agribisnis di Desa Sumillan Kecamatan Allla Kabupaten Enrekang. Metode penelitian yang digunakan adalah kualitatif. Data yang dikumpulkan dengan menggunakan instrumen berupa observasi, dokumentasi dan dikembangkan dengan wawancara terhadap informan. Tehnik analisis data yang digunakan dalam penelitian ini adalah model analisa interaktif, yaitu: Pengumpulan Data, Reduksi Data, Sajian Data, dan Penarikan Simpulan. Keabsahan data dalam penelitian ini diperiksa dengan menggunakan teknik triangulasi. Hasil penelitian ini menunjukan bahwa Penyuluhan dan pendampingan kepada pelaku pertanian dan perkebunan pemerintah berperan melalui pemberian bimbingan dan pengarahan yang intensif dan efektif kepada masyarakat sebagai upaya pengembangan sistem bisnis dalam pemasaran promosi hasil pertanian, pemerintah berposisi sebagai agen yang mempercepat pengembangan potensi daerah Strategi pemerintah daerah dalam pengembangan potensi unggulan dalam hal ini sayur dan buah-buahan dengan menggunakan analisis SWOT yang sejauh ini telah maksimal dalam menjalankan srtategi yang maksimal untuk digunakan pada masyarakat apalagi dalam bidang pertanian dan perkebunaan.
\end{abstract}

Kata kunci : pemerintah daerah, strategi, pasar agribisnis 


\section{A. PENDAHULUAN}

Kabupaten Enrekang adalah salah satu Kabupaten yang terletak di sebelah timur dari Provinsi Sulawesi Selatan. Kondisi sektor pertanian yang menonjol dalam struktur ekonomi Kabupaten Enrekang sangat relevan apabila sektor pertanian dikembangkan sebagai sektor unggulan yang dapat memberikan kontribusi positif bagi perkembangan ekonomi daerah. Dengan memperhatikan potensi yang ada seperti luas lahan pertanian, mata pencaharian sebagian besar penduduk adalah petani, serta memberikan kontribusi terbesar dalam perekonomian daerah (Tahun 2008 sebesar 55,15\% dari PDRB Kabupaten). Profil Kabupaten Enrekang.

Untuk mewujudkan visi tersebut, maka salah satu misi yang akan dilaksanakan yaitu mengembangkan berbagai produk pertanian komoditas unggulan Berbasis Ekonomi Masyarakat dan berorientasi pasar. Dalam rangka mewujudkan visi dan misi Kabupaten Enrekang tersebut salah satunya adalah membangun terminal agropolitan. Salah satu daerah yang mempunyai potensi strategis untuk pembangunan terminal agro di Kabupaten Enrekang, yaitu di Desa Sumillan Kecamatan Alla.

Terminal Agro yang selanjutnya disebut Sub Terminal Agribisnis merupakan tempat/jasa pemasaran hasil komoditi pertanian. Sub Terminal Agribisnis (STA) menurut konsep yang dibakukan olehSub Terminal Agribisnis (STA) Sumillan di Kecamatan Alla, dibangun pada tahun 2004.Tapi dalam pembangunan Sub Terminal Agribisnis (STA) ini tidak dibuat Feasibility Study atau Studi Kelayakan terlebih dahulu. Anggaran pembangunan STA Sumillan bersumber dari APBD Kabupaten dan APBN (Departemen Pertanian). Fasilitas yang dibangun pada Tahun 2004 yaitu kantor pengelola dan grosir sayuran. Selanjutnya pada tahun 2005 dibangun gudang penyimpanan, Tahun 2006 pengerasan jalan di Sub Terminal Agribisnis (STA) sepanjang $500 \mathrm{~m}$ dan tahun 2007 pengadaan sarana angkutan dan mobiler.

Sasaran utama pembangunan Sub Terminal Agribisnis (STA) Sumillan adalah untuk meningkatkan nilai tambah bagi petani dan pelaku pasar, khususnya terhadap hasil-hasil komoditas pertanian Kecamatan Alla. Sasaran lainnya adalah, untuk mendidik petani agar memperbaiki kualitas produk sekaligus mengubah pola pikir ke arah agribisnis, sehingga dapat meningkatkan pendapatan petani serta menjadi salah satu sumber Pendapatan Asli Daerah dari retribusi yang diperoleh, di samping untuk pengembangan akses pasar. Dengan melihat hasil komodioti pertanian di desa sumillan maka penulis tertarik melakukan penelitian mengenai strategi pemerintah daerah dalam pengembangan pasar agribisnis di desa sumillan kecamatan alla kabupaten enrekang.

\section{B. KONSEP STRATEGI}

Seiring dengan perkembangan disiplin ilmu, pengertian strategi menjadi bermacammacam sebagaimana dikemukakan oleh para ahli dalam buku karya mereka masingmasing. Pengertian strategi adalah suatu proses penentuan rencana para pemimpin puncak yang berfokus pada tujuan jangka panjang organisasi, disertai penyusunan suatu cara atau upaya bagaimana agar tujuan tersebut dapat dicapai. Selain definisidefinisi strategi yang sifatnya umum tersebut, ada juga pengertian strategi yang lebih khusus, seperti yang diungkapkan oleh dua pakar strategi, Menurut Salusu (1996) pengertian strategi adalah tindakan yang bersifat incremental (senantiasa meningkat) dan terus-menerus, serta dilakukan berdasarkan sudut pandang tentang apa yang diharapkan oleh para pelanggan di masa depan. Dengan demikian, strategi hampir dimulai dari apa yang terjadi dan bukan dimulai dari apa yang terjadi. terjadinya kecepatan inovasi pasar yang baru dan perubahan pola konsumen memerlukan komptensi inti (core competencies). Kata strategi berasal dari bahasa Yunani "strategia" yang diartikan sebagai "the art of the general" atau seni seorang panglima yang biasanya digunakan dalam peperangan. Dalam pengertian umum, strategi adalah cara untuk mendapatkan kemenangan atau mecapai tujuan.

Strategi pada dasarnya merupakan seni dan ilmu menggunakan dan mengembangkan kekuatan (ideologi, politik, ekonomi, social budaya dan hankam untuk mencapai tujuan yang 
telah ditetapkan sebelumnya. Menurut Clausewitz (dalam Salusu,1996) strategi adalah pengetahuan tentang penggunaan pertempuran untuk memenangkan peperangan. Sedangkan perang itu sendiri merupakan kelanjutan dari politik. Strategi adalah suatu cara dimana organisasi/lembaga akan mencapai tujuannya, sesuai dengan peluangpeluang dan ancaman-ancaman lingkungan eksternal yang dihadapi, serta sumber daya dan kemampuan internal.

Menurut Kaplan \& Norton (dalam Salasu, 1996) Strategi adalah seperangkat hipotesis dalam model hubungan cause dan effect. Strategi didefinisikan sebagai suatu proses penentuan rencana para pemimpin puncak yang erfokus pada tujuan jangka panjang organisasi, diserta penyusunan suatu cara atau upaya bagaimana agar tujuan tersebut dapat dicapai, strategi merupakan tindakan yang bersifat incremental (senantiasa meningkat) dan terus-menerus serta dilakukan berdasarkan sudut pandang tentang apa yang diharapkan oleh para pelanggan di masa depan.

Strategi adalah cara untuk mencapai tujuan berdasarkan analisa terhadap faktor internal dan eksternal anonym Strategi adalah keselarasan strategi dengan kebutuhan dan kemampuan dikaitkan dengan upaya penguatan kemampuan kepemimpinan (leadership), kewirausahaa (enterpreneurship) dan pengelolaan (managerial). Strategi adalah ilmu dan seni tentang penggunaan kekuatankekuatan politik, ekonomi, psikologi, dan militer satu bangsa atau kelompok bangsabangsa yang memungkinkan dukungan maksimal kepada kebijakan yang telah ditetapkan, baik saat damai maupun saat perang. (Salusu, 1996).

\section{KONSEP PEMERINTAH DAERAH}

Pemerintah adalah bagian dari Negara. Seperti banyak tercantum dalam teori mengenai Negara, unsur-unsur suatu Negara umumnya terdiri dari wilayah, rakyat, pemerintah dan kedaulatan.Sering pula unsur ini ditambah dengan tujuan Negara. Dengan kumpulan unsur-unsur Negara seperti ini menjadi jelas bahwa pemerintahan adalah alat atau sarana untuk mencapai tujuan Negara. Dengan demikian, makna pemerintah dan pemerintahan akan banyak tergantung dari isi tujuan Negara dan cara-cara yang dilakukan untuk mewujudkan tujuan Negara tersebut (Hamdi, 2002).

Menurut Syafei (2005) pemerintah adalah suatu ilmu dan seni. Dikatakan sebagai seni karena berapa banyak pemimpin pemerintahan yang tanpa pendidikan pemerintahan, mampu berkiat serta dengan kharismatik menjalankan roda pemerintahan. Sedangkan dikatakan sebagai suatu disiplin ilmu pengetahuan, adalah karena memenuhi syarat-syaratnya yaitu dapat, dipelajari dan diajarkan, memiliki objek, baik objek materi maupun formal, universal sifatnya, sistematis serta spesifik.

Pemerintahan berasal dari kata pemerintah, yang paling sedikit kata "perintah" memiliki empat unsur yaitu, ada dua pihak yang terkandung, kedua pihak tersebut saling memiliki hubungan, pihak yang memerintah memiliki wewenang, dan pihak yang diperintah memiliki ketaatan.

Apabila dalam suatu Negara kekuasaan pemerintahan, dibagi atau dipisahkan maka terdapat perbedaan antara pemerintahan dalam arti luas dengan pemerintahan dalam arti sempit. Pemerintahan dalam arti sempit hanya meliputi lembaga yang mengurus pelaksanaan roda pemerintahan disebut juga eksekutif, sedangkan pemerintahan dalalm arti luas selain eksekutif termasuk juga lembaga yang membuat peraturan perundang-undangan disebut legislatif dan yang melaksanakan peradilan disebut yudikatif.

\section{KONSEP PASAR AGRIBISNIS}

Pasar sebagai area tempat jual beli barang dengan jumlah penjual lebih dari satu baik yang disebut sebagai pusat perbelanjaan, pasar tradisional, pertokoan, mall, plaza, pusat perdagangan maupun sebutan lainnya. Pasar dalam pengertian ekonomi adalah situasi seseorang atau lebih pembeli (konsumen) dan penjual (produsen dan pedagang) melakukan transaksi setelah kedua pihak telah mengambil kata sepakat tentang harga terhadap sejumlah (kuantitas) barang dengan kualitas tertentu yang menjadi objek transaksi.

Kedua pihak, pembeli dan penjual mendapat manfaat dari adanya transaksi atau pasar.Pihak pembeli mendapat barang yang diinginkan untuk memenuhi dan 
memuaskan kebutuhannya sedangkan penjual mendapat imbalan pendapatan untuk selanjutnya digunakan untuk membiayai aktivitasnya sebagai pelaku eonomi produksi atau pedagang.sehingga akhirnya dapat menetapkan harga keseimbangan (harga pasar) dan jumlah yang diperdagangkan. Jadi, berdasarkan pernyataan diatas pasar adalah area tempat jual beli barang/ jasa dengan penjual lebih dari satu orang yang didalamnya. Proses interaksi antara permintaan (pembeli) dan penawaran (penjual) sehingga menetapkan harga dan jumlah yang disepakati oleh penjual dan pembeli.

Ensiklopedi ilmu-ilmu sosial mengartikan pasar adalah institusiyang memungkinkan terjadinya pertukaran melalui tawar-menawar atau pelelangan (Kuper, 2000: 609). Definisi pasar adalah penjual yang ingin menukarkan barang/jasa denganuang, dan pembeli yangingin menukar uang dengan barang dan ataujasa.

Pasar tradisional adalah pasar yang kegiatan para penjual dan pembelinya dilakukan secara langsung dalam bentuk eceran dalam waktu sementara atau tetap dengan tingkat pelayanan terbatas. Pasar tradisional adalah Pasar yang dibangun dan dikelola oleh Pemerintah Daerah, Swasta, Badan Usaha Milik Negara dan Badan Usaha Milik Daerah termasuk kerjasama dengan swasta berupa tempat usaha yang berbentuk toko, kios, los, dan tenda yang dimiliki/dikelola oleh pedagang kecil, menengah, koperasi dengan usaha skala kecil, modal kecil dan melalui proses jual beli barang dagangan dengan tawar menawar.

Dari beberapa pengertian diatas, pasar tradisional adalah tempat pasar yang dibangun dan dikelola oleh Pemerintah, Pemerintah Daerah, Swasta, Badan Usaha Milik Negara, dan Badan Usaha Milik Daerah yang merupakan tempat bertemunya penjual dan pembeli dalam proses transaksi jual beli secara langsung dalam bentuk eceran dengan proses tawar nawar dan bangunannya biasanya terdiri dari kios-kios atau gerai, los, dan dasaran terbuka. Pasar tradisional biasanya ada dalam waktu sementara atau tetap dengan tingkat pelayanan terbatas.

Sedangkan pasar modern tidak banyak berbeda dari pasar tradisional, namun pasar jenis ini penjual dan pembeli tidak bertransaksi secara langsung melainkan pembeli melihat label harga yang tercantum dalam barang (barcode), berada dalam bangunan dan pelayanannya dilakukan secara mandiri (swalayan) atau dilayani oleh pramuniaga. Barang-barang yang dijual, selain bahan makanan makanan seperti; buah, sayuran, daging sebagian besar barang lainnya yang dijual adalah barang yang dapat bertahan lama. Contoh dari pasar modern adalah pasar swalayan dan hypermarket, supermarket, dan minimarket.

\section{E. METODE PENELITIAN}

Upaya pengumpulan data yang diperlukan dalam penelitian, penulis memilih Sub Terminal Agribisnis (Pasar Agro) di Desa Sumillan Kecamatan Alla, Kabupaten Enrekang. Penelitian ini dilakukan di Desa Sumillan. Jenis penelitian yang akan dilakukan adalah penelitian kualitatif, artinya data yang dikumpulkan berasal dari hasil wawancara, observasi secara langsung, catatan lapangan, dokumen pribadi, catatan memo dan dokumen resmi lainnya. Tipe penelitian yang digunakan adalah tipe penelitian deskriptif kualitatif yaitu merupakan penelitian yang menggambarkan secara jelas tentang strategi yang digunakan oleh pemerintah daerah Kabupaten Enrekang.

\section{F. HASIL DAN PEMBAHASAN}

Strategi Pemasaran pada dasarnya adalah suatu rencana yang menyeluruh serta terpadu dan menyatu dibidang pemasaran barang dan jasa.Dengan perkataan lainnya strategi pemasaran itu adalah serangkaian tujuan dan sasaran kebijakan, serta aturan yang memberi arah kepada usaha-usaha pemasaran barang dan jasa. Strategi Pemasaran adalah wujud rencana yang terarah dibidang pemasaran untuk memproleh suatu hasil yang optimal.

Strategi pemasaran merupakan rangkaian suatu kegiatan yang terarah untuk 
mencapai sasaran dan dengan pola berpikir yang inovatif dan kreatif, untuk menghadapi kecenderungan yang terjadi di dalam perusahaan maupun di luar perusahaan, yang akan berpengaruh terhadap kepentingan maupun masa depan Pasar Agribisnis.

\section{Deskripsi Strategi So (Strenghts Opportunities)}

Dalam meningkatkan hasil pertanian sangat diperlukan fasilitas, pemerintah berusaha menciptakan atau memfasilitasi suasana yang tertib, nyaman dan aman, termasuk memfasilitasi sarana dan prasarana. Pemerintah telah memfasilitasi masyarakat petani melalui kelompok tani berupa, beberapa pompa air, selang/pipa air, mesin pendingin sayur-sayuran yang di tempatkan di pasar Agribisnis, mobil pengangkut hasil pertanian yaitu mobil box, mobil truk, mobil 3/4. Berikut hasil kutipan wawancara dengan beberapa narasumber terkait dengan indikator fasilitas, wawancara dengan masyarakat;

"Menurut saya pemerintah harus lebih memperhatikan masyarakat terutama di desa-desa Kabupaten Enrekang ini, apalagi berbicara masalah pertanian, karena sebagian besar masyarakat Enrekang bergerak di bidang petanian dan perekebunaan jadi pemerintah khusunya Dinas Pertanian dan Perkebunaan harus betul-betul memperhatikan sarana dan prasaran untuk menunjang pertanian yang ada di kampung kita ini penyediaan fasilitas adalah hal yang paling penting untuk menunjanng tinggi dan rendahnya hasil produksi pertanian, penyediaan fasilitas seperti perintisan jalan tani dan juga penyediaan teknologi. Bisah kita lihat sampai saat ini banyak jalan tani yang tidak bisah dilewati kendaraan pengangkut hasil pertanian". (wawancara, $A H$ ).

Senada dengan pendapat di atas terkait dengan bantuan dana dari Dinas Petanian dan Perkebunaan untuk penydiaan fasilitas dalam menunjang hasil pertanian dan perkebunaan Desa Sumillan.
"Terbatasnya fasilitas untuk masyarakat disebebkan kurangnya dana APBD untuk dinas petanian dan perkebunaan hal inilah dek yang menyebabkan terbatas dan tidak meratanya fasilitas sarana dan prasarana untuk meningkatkan hasil pertanian (wawancara, MR)"

Wawancara di atas menunjukan bahwa adanya kelemahan dalam peran Pemerintah seharusnya menunjang atau membantu masyarakat dan juga memberikan pelatihan kepada masyarakat agar bisa menguasai teknologi untuk menunjang pertanian mereka sehingga tidak melewati proses yang lama. Pemerintah seharusnya mengulanginya pada tahun tahun berikutnya. Dimana itu sebuah tanggung jawab pemerintah selaku pelayan bagi masyarakat khususnya di Kabupaten Enrekang.

"Di Desa Bubunbia Kecamatan Baroko Kabupaten Enrekang. Saya sangat merasakan kurangnya perhatian dari pemerintah dalam hal ini bantuan pasilitas seperti teknologi dan takkala pentinganya yaitu penyediaan atau perintisan jalan tani. Seperti saya dan masih banyak rekanrekan petani yang merakasaanny kurangnya perhatian dari pihak pemerintah menyebabkan banyaknya hasil pertanian yang rusak/busuk karna tidak ada alat transpotasi yang bisah mengangkut pasca panen, apa lagi musim hujan seperti ini.( Wawancara, SR)

Wawancara di atas menunjukan bahwa adanya kelemahan dalam peran pemerintah yang seharusnya menunjang atau membantu dalam campur tangan pemerintah kepada masyarakat dengan bentuk pemberian fasilitas, baik alat penunjang pertanian maupun perkebunan.

Pada tahun sebelumnya dimana Kabupaten Enrekang di bawah pimpinaan $\mathrm{H}$. Latinro Latunrung hasil pertanian Kabupaten Enrekang bisa dikatakan buruk disebabkan kurangnya perhatian pemerintah khususnya dari Dinas Pertanian dan Perkebunaan. Dengan adanya program pemerintah yaitu penyuluhan dan pendampingan diharapkan mampu meningkatkan hasil petanian di 
Kabupaten Enrekang. Pendampingan seperti yang telah dilakukan oleh pemerintah daerah yaitu membantu masyarakat petani dalam pembuatan bibit unggul sayur-sayuran dan juga pemerintah rutin mengadakan pengecekan di pasar agribisnis. terkait dengan indikator penyuluhan dan pendampingan terhadap pelaku petani seperti hasil wawancara dengan staf Dinas Pertanian dan Perekebunaan.

"Terimah kasih, saya selaku pemerintah Kabupaten khusunya dalam hal ini dinas pertanian dan perkebunaan, Sejak awal kepemimpinaan Muslimin bando terkait dengan RPJMD yaitu pendampingan dan penyuluhan kepada pelaku petani itu sudah kami realisasikan untuk beberapa kecamatan yang ada di Kabupaten Enrekang seperti yang kami laksanakan pada akhir tahun 2014 lalu pada tanggal 24 Desember 2014"( wawancara, MN).

Wawancara diatas menunjukan bahwa pemerintah sudah berperan dalam menunjang atau membantu petani dalam penyuluhan dan pendampingan terhadap pelaku agribisnis dan seminar Adanya campur tangan pemerintah sehingga masyarakat sangat terbantu dan menambah kekuatan tersendiri dalam berkebun maupun bertani, yang di mana pada wawancara di atas sebuah kelompok tani mendapatkan pengetahuan dan tehniktehnik dalam bercocok tanam.

Senada dengan hasil wawancara di atas.

"Dengan adanya program pemerintah yaitu penyuluhan dan pendampingan pelaku petani ini sudah sangat kami rasakan dampak fositinya saya sebagai ketua gapoktan (gabungan kelompok tani) di Kecamatan Alla sangat berterimah kasih, dengan adanya program ini di harapkan hasil pertanian dan perkebunaan lebih meningkat dan hasilnya juga berkulitas dan kualitas SDM takkala pentingnya". (wawancara, MN).

Wawancara diatas menunjukan bahwa adanya perana pemerintah dalam menunjang atau membantu petani dalam bantuan berupa penyuluhan, dalam hal ini masyarakat di ajarkan bagaimana bercocok taman yang baik dan keaktifan kelompok tani maupun perseorangan yang langsung bisa merasakan campur tangan pemerintah kepada masyarakat sangat terbantu menambah kekuatan tersendiri dalam berkebun bertani, yang di mana pada wawancara di atas ketua kelompok tani.

\section{Deskripsi Strategi WO (Weaknesse} Opportunities)

Dengan adanya pendistribusian langsung semua hasil pertanian dan perkebunaan akan di stribusikan langsung ke beberapa kecamatan yang ada di Kabupaten Enrekang melalui pasar Agribisnis yang ada di desa Sumillan, bukan hanya di Kabupaten Enrekang melaikan daerah daerah luar yang ada di Indonesia seperti Kalimantan, kendari, luwu, busgis, Makassar, jeneponto, Bantaeng Surako, Toraja, palopo dan lain-lain.

Hasil pertanian yang masuk masuk ke pasar angribisnis melalui pedagang pengempul, dan semua hasil pertanian yang ada di Kabupaten Enrekang masuk di pasar agribisnis kemudian langsung di distribusikan keluar daerah.

Tanpa adanya pendistribusian langsung, hasi pertanian dalam hal ini sayuran akan menumpuk di pasar agribisnis, dan akan membusuk. Strategi pemerintah seperti yang ada pada indikator distribusi hasil pertanian.

Berikut hasil kutipan wawancara dengan beberapa informan terkait dengan indikator distribusi, wawancara dengan masyrakat;

"Berbicara soal distribusi hasil petanian,

menurut saya di pasar agribisnis ini sangat memungkinkan melakukan distribusi hasil pertanian, di mana tingginya hasil pertanian dari Kabupaten Enrekang yang masuk kepasar Agribisnis di tambah dengan banyaknya pedagang hal ini yang lebih memungkinkan untuk pendistribusian langsung karna pedagang berperan untuk mengumpulkan hasil pertanian dari parah petani di berbagai desa dan kecamatan di Kabupaten Enrekang (Wawancara, KH)"

Dari hasil wawancara penulis di atas dapat diketahui bahwa ada peluang dalam strategi pemasaran sayur-sayuran, karena adanya perhatian dari pihak pemerintah 
terhadap produksi sayur sayuran serta Dinas Pertanian dan Perkebunaan Kabupaten tumbuhnya keseriusan petani dalam Enrekang. Pemerintah sudah merealisasikan menjalankan sebuah pekerjaannya, sehingga tanggung jawabnya yaitu peningkatan mutu mendapatkan peluang dalam peningkatan kelompok tani melalui program penyuluhan dan produksi sayuran dan buah-buahan yang di pendampingan terhadap pelaku petani.

mana peluangnya sangat besar dilihat dari meningkatnya produksinya.

"Potensi hasil pertanian seperti sayunsayuran di Kabupatan Enrekang yang di kumpulkan di pasar agribisnis desa sumillan sangat baik karena banyaknya pembeli dan pedagang dari luar daerah yang mencari sayur sayuran untuk dijual kembal dan dapat dijadikan sebagai sebuah produk, produk produk ungulan baik $\mid d i$ dalam daerah maupun di luar daerah Kabupaten Enrekang ini dek. Berkat kerja sama yang baik antara masyarakat dan pemerintah". (Wawancara, $M N)^{\prime \prime}$.

Berikut hasil kutipan wawancara dengan beberapa narasumber terkait dengan peningkatan mutu kelompok tani, wawancara dengan staf Dinas Petanian dan Perkebunaan ;

"Terkait dengan salah satu program pemerintah daerah dinas pertanian dan perkebunaan yaitu penyuluhan dan pendampingan itu adalah tanggung jawab dari bidang kasi konservasi dan perlindungan, tim penyuluh selain itu pemerintah juga memberikan pelatihan(pemilihan bibit unggul) kepada masyarakatpetani.(Wawancara, SI)"

Dengan adanya program ini di harapakan mempu menambah pengetahuan kepada masyarakat petani, agar mengetahui

Senada dengan kutipan wawancara di cara bercocok tanam yang baik di Desa atas terkait deangan pendistribusian hasil Sumullan ini. Seperti hasil wawancara dengan pertanian dan perkebunaan jawaban yang salah satu staf Dinas Pertanian dan sama dengan hasil wawancara di bawah ini. Perkebunaan, jawaban yang sedikit berbeda

"Berdarkan komoditi hasil petanian dengan hasil wawancara dengan salah satu yang masuk ke pasar agribisnis sangat ketua kelompok tani di Desa Sumillan

besar peluang untuk di distribusikan langsung ke daerah-daerah yang ada di Sulsel seperti Toraja, Palopo, Jeneponto, Takalar, Luwu, Sorowako. (Wawancara, KP)"

Dari hasil wawancara diatas dapat diketahui bahwa ada peluang terhadap strategi pendistribusian hasil pertanian. Pengembangan Pasar Agribisnis dimana peluang terjadi karena meningkatnya hasil pasca panen hal ini dapat kita dilihat dari bertambahnya pedagang dari luar daerah yang memilih Pasar Angribisnis Desa Sumillan sebagai tempat membeli sayur sayuran yang kemudian akan di jual kembali. Dengan meningkatnya kualitas dari pasca panen petani dan pemerintah khususnya di Kabupaten Enrekang harus di pertahankan lebih baik dari sebelumnya untuk mendapat peluang yang lebih baik pula.

Peningkatan mutu kelompok tani adalah tanggung jawab dari Pemerintah dalam hal ini tanam.

\begin{abstract}
"Sudah diadakan pertemuan (pelatihan) di kecamatan,alla yang di ikuti sama semua ketua dan anggota kelompok tani, dimana pertemuan biasah di laksanakan di aulah pasa'baru (pasar agribisnis). Pertmuan masyarakat petani dengan pedagang di pasar agribisnis Sumillan pernah juga di laksanakan di balai desa". (wawancara, SN)
\end{abstract}

Wawancara diatas menunjukan bahwa pemerintah sudah berperan dalam menunjang atau membantu petani dalam penyuluhan dan pendampingan terhadap pelaku agribisnis dan seminar Adanya campur tangan pemerintah sehingga masyarakat sangat terbantu dan menambah kekuatan tersendiri dalam berkebun maupun bertani, yang di mana pada wawancara di atas sebuah kelompok tani mendapatkan pengetahuan dan tehnik-tehnik dalam bercocok 
Dari hasil wawancara diatas dapat

\section{Deskripsi Strategi ST (Strength} Threats )

Promosi hasil pertanian dan perkebunaan merupakan upaya untuk memberitahukan atau menawarkan produk dengan tujuan menarik konsumen untuk membeli atau mengkonsumsinya. Dengan promosi produsen atau distributor mengharapkan kenaikan angka penjualan. Tanpa adanya promosi strategi seseorang untuk menggapai tujuan dengan mengatasi tantangan itu dengan maksimal agar strategi yang dijalankan bias produktif dengan melakukan wawancara langsung kepada masyarakat di Kabupaten Enrekang di beberapa desadesa yang membahas tantangan (threat) langsung dari informan dengan indicator tantangan startegi startegipemerintah.

Berikut hasil kutipan wawancara dengan beberapa informan terkait dengan indikator promosi hasil pertanian.

"Dari segi promosi, kami telah mempromosikan hasil pertanian dan perkebunaan seperti yang di lakukan oleh kelompok tani Di Desa Tampo Kecamatan Anggeraja Kabupaten Enrekang dan kerja sama dengan tokoh tokoh masyarakat desa dari berbagai kecamatan di Kabupaten Enrekang dalam mengadakan pameran hasil pertanian dan perkebunaan (Wawancara, KT)

Dari hasil wawancara diatas dapat diketahui bahwa masyarakat dan pemerintah telah mempromosikan hasil pertanian melalui pameran hasil pertanian dan juga media baik online maupun cetak. Setiap hal memiliki pertentangan sama halnya dengan hasil wawancara peneliti dengan masyarakat petani yang menyatakan bahwa:

"Tingkat pelayanan pemerintah masih sangat kurang karena masih banyak desa-desa yang tidak dijangkau sehingga tidak dapat dikenal, akhirnya banyak petani yang hasil panennya kurang terjual. Pada hal sudah mengikuti pelatihan dan mendapatkan bantuan dana maupun alat bantu panen". (Wawancara, MR).
"Kami selaku Pemerintah Daerah, Dinas Pertanian dan Perkebunaan Kabupaten Enrekang dimana mempunyai program kerja maupun visi dan misi yang kami harus jalankan berbagai strategi yang kami lakukan untuk kesejahteraan rakyat. Bahkan kami menjadikan hasil pertanian Kabupaten Enrekang, sehinggaa bantuan ataupun partisipasi kami ke masyarakat dengan mengadakan penyuluhan pendampingan kepada pelaku petani dari beberapa kecamatan yang ada di Kabupaten Enrekang dan juga pelatihan, bantuan dana ataupun memberikan bibit maupun berupa alat yang bisa menunjang hasil pertanian sehingga bisa di pasarkan di dalam maupun di luar daerah". (Wawancara, MA)

Kerja sama antara pedagang pengumpul dengan pedagang yang mendristribusikan hasil pertanian dengan ini di harapakan mampu meningkatkan penjualan hasil pertanian di dalam daerah bahkan di luar daerah yang ada di Indonesia. Dan campur tangan pemerintah dalam hal ini Dinas Pertanian dan Perkebunaan di harapakan mampu memfasilitasi pedagang untuk lebih meningkatkan penjualan hasil pertanian dan perkebunaan. Berikut kutipan wawancara peneliti dengan salah satu staf di Kantor Pasar Agribisnis Desa Sumillan.

"Berdarkan komoditi hasil petanian yang masuk ke pasar agribisnis sangat besar peluang untuk di distribusikan langsung ke daerah-daerah yang ada di Indonesia. Seperti Toraja, Palopo, Jeneponto, Takalar, Kalimantan, Samarinda, Kediri luwu, Suroako. (Wawancara, KP)"

Senada dengan hasil wawancara penelitih dengan salah satu staf kantor pasar agribisnis, jawaban yang berbedah dengan 
jawaban salah satu staf Dinas Pertanian dan Perkebunaan Kabupaten Enrekang, berikut hasil wawancara penelitih dengan salah satu

sataf kantor Dinas Pertanian
Perkebunaan Kabupaten Enrekang.

"Iya sangat penting, kerja sama antara pemerintah dareah dengan pedagang di Pasar Agribisnis dan juga parah petani (kelompok tani yang aktif) Kabupaten Enrekang. Kerja sama yang efektif di harapakan mampun mengkatkan penjualan hasil pertanian. Kerja sama juga di harapakan lebih meningkatkan silaturahmi antara pemerintah, pedagang, petani (kelompok tani). (wawancara, NT)

Dari analisis wawancara di atas dapat diketahui bahwa pemerintah telah berupaya menjalin kerja sama yang baik antara pemerintah, pedagang, petani (kelompok tani ).

\section{Strategi WT (Weakness Threats)}

Upaya dalam peningkatan pelayanaan kepada masyarakat dan peningkatan SDM adalah salah satu strategi pemerintah dalam pengembangan pasar agribisnis desa sumillan, hal ini sudah di realisasikan oleh Pemerintah dengan mengadakan penyuluhan dan pendampingan kepada pelaku petani dan memberikan pelatihan tentang bagaimana cara menggunakan teknologi pertanian yang lebih canggih.

Dengan adanya hal demikian diharapkan mampu meningkatkan kualitas pelayanan kepada masyarakat petani dan juga meningkatkan kualitas SDM, sehingga mampu meningkatkan hasil petanian yang lebih tinggi dan berkualitas.

Terkait dengan upaya memperbaiki tingkat pelayanan kepada masyarakat dan SDM petani, kutipan wawancara dengan salah satu staf dinas petanian dan perkebunaan.

"Diharapkan dengan adanya program ini kelompok tani jadi aktif karna pendampingan Pemerintan (Dinas Pertanian dan Perkebunaan) kepada kelompok tani secara rutin di beberapa Kecamatan dan desa di Kabupaten Enrekang dilakukan (wawancara, AR)"
Dari hasil wawancara diatas dapat diketahui bahwa pemerintah telah bereupaya dalam peningkatan pelayanaan kepada masyarakat dan peningkatan SDM.

\section{G. PENUTUP}

Strategi Pemerintah Daerah dalam Pengembangan Pasar Agribisnis di Desa Sumillan Kecamatan Alla Kabupaten Enrekang, dengan menggunakan strategi, penyuluhan dan pendampingan terhadap pelaku petani, fasilitas untuk menunjang hasil pertanian dan perkebunan, promosi hasil pertanian, distribusi hasil Pertanian dan pelatihan. Kegiatan penyuluhan dan pendampingan kepada pelaku pertanian dan perkebunaan, pemerintah berperan melalui pemberian bimbingan dan pengarahan yang intensif dan efektif kepada masyarakat sebagai upaya pengembangan sistem bisnis dalam pemasaran.

Fasilitas untuk menunjang hasil pertanian dan perkebunan, pemerintah berusaha menciptakan atau menfasilitasi suasana yang tertib nyaman dan aman termasuk menfasilitasi tersedianya sarana dan prasarana pembangunan untuk menunjang hasil produksi yang tinggi. Promosi hasil pertanian, pemerintah berposisi sebagai agen yang mempercepat pengembangan potensi daerah dan negara yang kemudian bisa menjadi modal sosial untuk membangun partisipasi.

Pemerintah sangat diharapkan berperan aktif dalam pendistribusian hasil pertanian melalui pasar agribisnis desa sumillan, pemerintah juga harus bekerja sama dengan petani dan juga pedagang baik pedagang dari dalam daerah maupaun pedagang yang ada di luar daerah, dengan kerja sama yang baik di harapakan dapat melancarkan distribusi sayur dan buah-buahan yang ada di pasar agribisnis. Strategi pemerintah daerah dalam pengembangan potensi unggulan dalam hal ini sayur dan buah-buahan dengan menggunakan analisis SWOT yang sejauh ini telah maksimal dalam menjalankan srtategi yang maksimal untuk digunakan pada masyarakat apalagi dalam bidang pertanian dan perkebunaan sehingga pemerintah dapat mensejahterahkan masyarakatnya serta dapat meningkatkan produktivitas serta pemasaran hasil petanian sayuran dan buah-buahan ke luar daerah bahkan ke luar negeri. 


\section{DAFTAR PUSTAKA}

Salusu, J. 1996. Pengambilan Keputusan Strategik: Untuk Organisasi Publik dan Organisasi Non Profit. Jakarta : Gramedia Widiasarana Indonesia.

Suhendra, K. 2006. Peranan Birokrasi Dalam Pemberdayaan Masyarakat. Bandung : Alfabeta.

Suryana, Yuyus dan Bayu, Kartib. 2011. Kewirausahaan. Jakarta : Kencana.

Sutrisno, Edy, 2009.Manajemen Sumber daya Manusia. Jakarta : Kencana.

Syafei, Inu Kencana. 2005. Manajemen Pemerintahan. Bandung : Pustaka Eka Cipta

Suwarsono, Muhammad, 2008. Manajemen Strategi : Konsep dan Kasus. Yogyakarta : YKPN Press.

Widjaja, H.A.W., 2007. Otonomi Daerah dan Daerah Otonom. Jakarta: PT RajaGrafindo Persada.

\section{Dokumen :}

Undang - Undang Nomor 32 Tahun 2004 Tentang Pemerintah Daerah. 